\title{
Motivación y satisfacción laboral del personal técnico administrativo de la enseñanza
}

\author{
Work Motivation and Satisfaction of \\ Technical-Administrative Staff in Education \\ Motivação e satisfação no trabalho dos servidores \\ técnicos administrativos em educação
}

Fernanda Costa Barros

Universidade Federal de Goiás, Brasil

E-mail: fernandabarros32@yahoo.com.br

\author{
André Vasconcelos Silva \\ Universidade de Brasilia, Brasil. \\ E-mail: andre_vasconcelos_silva@ufg.br
}

Fecha de Recepción: 30/03/2021 Fecha de Aceptación: 15/07/2021

Palabras clave - satisfacción laboral

- funcionarios públicos

- rendimiento

- comportamiento

- cuestionario de satisfacción laboral

\section{Vitória Ribeiro}

Universidade Federal de Catalão, Brasil

E-mail: vitoria.ribeiro210799@gmail.com

\section{Resumen}

La búsqueda de mejoras en el rendimiento de las organizaciones está directamente relacionada con el comportamiento de los empleados. Entre los factores que influyen en su comportamiento está la satisfacción laboral. Este artículo pretende identificar los factores que influyen en la satisfacción laboral de los técnicos administrativos en educación. Medición de la satisfacción del personal administrativo en activo de las Instituciones Federales de Enseñanza Superior (IFES) del Estado de Goiás mediante el uso de cuestionarios de satisfacción laboral. En cuanto a los resultados, observamos que el $54,6 \%$ de las TAEs participantes en la encuesta están parcial o totalmente satisfechas, sólo el 2,5\% están totalmente insatisfechas, el 10,1\% están parcialmente insatisfechas y el $32,8 \%$ se concentran en el rango de indiferentes.

\footnotetext{
Abstract

The pursuit of improvement in the performance of organizations is directly related to the behaviour of their employees. Work satisfaction is one of the factors that have an impact on their behaviour. This article aims to identify the factors which influence technical-administrative staff's satisfaction at work in the field of education.
} 
Keywords

- job satisfaction

- public servants

- performance

- behavior

- job satisfaction questionnaire

Palavras-Chave

- satisfação no trabalho

- servidores públicos

- desempenho

- comportamento

- questionário de satisfação no trabalho
The satisfaction of active technical-administrative staff of the federal higher education institutions (IFES) of the State of Goiás has been measured through the use of job satisfaction questionnaires. The results show that $54.6 \%$ of the participants in the survey are partially or totally satisfied; only $2.5 \%$ are totally dissatisfied; $10.1 \%$ are partially dissatisfied and $32.8 \%$ are within the indifferent interval.

\section{Resumo}

A busca de melhorias no desempenho nas organizações está diretamente relacionada ao comportamento dos colaboradores. Dentre os fatores que influenciam o comportamento destes, destaca-se a satisfação no trabalho. Este artigo tem como objetivo identificar fatores que influenciam a satisfação no trabalho para os técnicos administrativos em educação. Mensurando a satisfação dos servidores técnicos administrativos ativos das instituições federais de ensino superior (IFES) do Estado de Goiás através da utilização de questionários sobre satisfação no trabalho. Quanto aos resultados notase, que $54,6 \%$ dos TAEs participantes da pesquisa estão parcialmente ou totalmente satisfeitos, somente 2,5\% totalmente insatisfeitos, $10,1 \%$ parcialmente insatisfeitos e $32,8 \%$ se concentraram no intervalo indiferente. 